\title{
Virological and molecular
} investigation on specimens from buffaloes suspected to be infected by buffalopox virus in Egypt 2019

\begin{abstract}
In this study, skin lesions from buffaloes showing clinical signs of buffalopox infection were tested to isolate and identify the buffalopox virus (BPXV). Clinical examination of infected buffaloes was performed and visible clinical signs recorded. Skin scabs from infected buffaloes were collected and used for virus isolation on embryonated chicken egg (ECE) and tissue culture cell lines. The isolated BPXV was identified and characterized using polymerase chain reaction (PCR). The infected buffaloes displayed fever, skin eruptions, enlargement of superficial lymph nodes, emaciation and drop in milk yield. The ECE inoculated with the prepared
\end{abstract}

skin scab samples showed clear raised white pock lesions on the chorioallantoic membrane (CAM). The inoculated tissue cultures (VERO and BHK cell lines) revealed a cytopathic effect (CPE) including rounding, clumping with cytoplasmic granulation and cluster formation. PCR for the C18L specific BPXV gene was carried out on the virus infected tissue culture produced 368 bp bands. Human infection with BPXV was also recorded. It was concluded that BPXV is circulating in Egyptian buffaloes, causing economical losses and infection in contact humans.

Key words: buffalopox; virological; molecular; diagnosis; Egypt

\section{Introduction}

Buffalopox virus (BPXV) is a contagious viral disease that mainly infects buffaloes. It has been reported in young and old buffaloes and may also be transmitted by insects (Venkatesan et al., 2010a). The disease occurs in two clinical forms including mild and severe forms.

The incubation period of BPXV in buffaloes is 2 to 4 days (Ghosh et al., 1977). The BPXV disease may be

Christine A. MIKHAEL, Farid F. ZAKI, Agriculture Research Center (ARC); Central Laboratory for Evaluation of Veterinary Biologics (CLEVB), El-Seka-Baida Street, Abbasia, Cairo, Egypt; Fayez A. SALIB*, (Corresponding author, e-mail: Salibfayez74@cu.edu.eg), Faculty of Veterinary Medicine, Cairo University, Egypt 
associating with high morbidity $(80 \%)$ (Borisevich et al., 2016), though it has a low mortality rate and an adverse effect on the productivity and working capacity of animals, resulting in large economic losses (Singh et al., 2007a; Venkatesan et al., 2010b).

Characteristic clinical signs of BPXV infection could be summarized as skin lines lesions on the udder, teats, thighs, hindquarters, inguinal region, base of the ears, over the parotid gland, inner aspect and base of eyes and ear (Sharma, 1934, Bhatia, 1936; Wariyar, 1937; Singh and Singh, 1967; Mallick and Dwivedi, 1982; Mallick, 1988). Severe forms show generalized rash and secondary bacterial otitis may be observed (Chandra et al., 1987; Ramakrishna and Ananthapadmanabham, 1957). CABI (2019) reported that BPXV infection is mostly recognised in lactating animals, and severe infections in lactating animals is accompanied with mastitis and reduction of milk yield (Singh et al., 2006a).

Buffalo pox infection was first recorded in India in 1934. Since then, several outbreaks have occurred in different countries, including Pakistan, Nepal, Iran, Indonesia, Bangladesh, Egypt, Russia and Italy (Essbaurer et al., 2010; Eltom et al., 2020). The causative agent of the disease was not identified until 1977, when it was isolated and characterized by Singh and Singh in 1967 (Anand and Butchaiah, 2004; Borisevich et al., 2016).

BPXV is a member of the Poxviridae family, grouped as Orthopoxvirus (OPV) genus and subfamily Chordopoxvirinae (Van Regenmortel et al., 2000). Its viral particle is brick shaped and measures 280-330 nm by 200-250 nm in size. Structurally, it resembles other OPVs; especially Vaccinia Virus (VACV), and there is a view that BPXV might be derived from VACV. It is possible that it became pathogenic to humans and animals. (Singh et al., 2007; Borisevich et al., 2016).

The known hosts of BPXV are the domestic buffaloes (Bubalus bubalis), cow, guinea pigs, suckling mice and humans (Goyal et al., 2013).

Clinical examination and specimen collection from infected animals is the first step in BPXV infection diagnosis. Samples are examined under electron microscopy, and the virus is isolated from lesion scabs by inoculation on ECE and cell culture lines, plaque assay and neutralization test, using PCR and Partial genome sequencing (Eltom et al., 2020).

BPXV could be propagated in a wide range of cell cultures as chick embryo fibroblast (CEF), pup kidney cells, Vero cells and Baby hamster kidney cells (BHK); showing a cytopathic effect (CPE) (Eltom et al., 2020). Scab samples were collected from infected buffaloes and then prepared and passaged on the BHK-21 and Vero cells to isolate the BPX virus (Goraya et al., 2015; Yadav et al., 2010).

The PCR is a fast and sensitive method for the detection of orthopox viral DNA. Several gel-based PCR methods have been described for the detection of orthopox viral DNA (Meyer et al., 1993, 1997; Ropp et al., 1995; Balamurugan et al., 2009).

PCR for the BPXV C18L gene could differentiate BPXV from other members of OPV, particularly VACV, to confirm the diagnosis of BPXV (Singh et al., 2008). The BPXV C18L gene encodes the ankyrin repeat protein that determines the virus host range (Borisevich et al., 2016). Primers for the $C 181$ gene amplify a 368 bp PCR product unique for BPXV (Eltom et al., 2020).

FAO/WHO Joint Experts identified BPXV as an important zoonotic disease (Eltom et al., 2020), as it infects humans, especially those in close contact with infected buffaloes. Typical pox lesions have been observed on animal handlers 
(Goraya et al., 2015; Borisevich et al., 2016). In humans, the virus causes lesions restricted to the hands, forehead, eyes, face, and buttocks, and also causes lymphadenopathy. Milking of infected buffalo is one of the major modes of transmission (Gurav et al., 2011). BPXV infection was also recorded in noncontact children, indicating its high virulence (Gore et al., 2020).

In Egypt, buffalo pox disease reported by Tantawi et al. (1976, 1977), who isolated four virus isolates in 1973 from an outbreak in Egyptian water buffaloes. All four isolates were antigenically related to Vaccinia. Al Gaabary and Abuo Rawash (2004) recorded different clinical signs in the El-Gerbia outbreak of 2002-2003.

There is lack of data about BPXV in Egypt, that indicates the need to focus on its infection, isolation using tissue culture and ECE and identification by PCR.

The goal of this study was to record the incidence of BPXV in Egypt and confirm the viral isolation and molecular characterization of the buffalo pox virus in Egypt as a means of controlling the disease using suitable diagnostic and prophylactic measures.

\section{Materials and Methods}

\section{Animals}

A total of six Buffaloes with clinical signs of BPXV located in the Giza Governorate were investigated by measuring body temperature, examining skin and superficial lymph nodes.

Clinical examinations, observations of lesions and complications for all examined buffaloes were carried out and recorded according to (Radostits et al., 2010). The BPXV clinically infected buffaloes, contact animals and infected humans are presented in Table 1.

\section{Sample collection and preparation}

Skin scabs from six clinically buffalopox virus infected buffaloes were collected and transferred to the laboratory under chilled conditions in transport medium - phosphate buffered saline (PBS) at pH 7.4 containing antibiotics. Samples were stored at $-20^{\circ} \mathrm{C}$ for BPXV isolation.

For virus isolation, skin scab samples were minced separately using sterile scissors and forceps and then ground using sterile techniques with a pestle in a mortar containing sterile sand. Ten millilitres of PBS containing gentamycin

Table 1. Buffalopox virus clinically infected buffaloes, contact animals and infected humans

\begin{tabular}{|c|c|c|c|c|c|}
\hline $\begin{array}{c}\text { Buffalo pox } \\
\text { infected } \\
\text { buffalo }\end{array}$ & Sex & Age & $\begin{array}{c}\text { Contact } \\
\text { animals }\end{array}$ & $\begin{array}{r}\text { Infected } \\
\text { contact } \\
\text { animals }\end{array}$ & $\begin{array}{r}\text { Infected human in } \\
\text { contact }\end{array}$ \\
\hline 1 & Female & $\begin{array}{c}18 \text { months } \\
\text { (pregnant) }\end{array}$ & 3 & Nil & $\begin{array}{r}\text { One (hands and mouth } \\
\text { skin lesions) }\end{array}$ \\
\hline 2 & Female & 12 months & 4 & $\begin{array}{c}\text { One } \\
\text { (7 months, } \\
\text { female) }\end{array}$ & Nil \\
\hline 3 & Female & 8 months & 5 & Nil & Nil \\
\hline 4 & Male & 10 months & 2 & Nil & One larm and mouth \\
\hline 5 & female & $\begin{array}{c}24 \text { months } \\
\text { (lactating) }\end{array}$ & 3 & Nkin lesions
\end{tabular}

N.B: Six BPXV infected buffaloes (five infected and one infected contact animals) 
(0.1 mg/mL), ampicillin (0.05 mg/mL) and fungistatine were added. The suspensions were left to stand overnight at $4^{\circ} \mathrm{C}$. The samples were partially clarified by centrifugation at $2000 \mathrm{rpm}$ for 3-5 min to remove gross particles and the supernatant was filtered with $0.45 \mu \mathrm{m}$ membrane filters, aliquoted and stored at $-80^{\circ} \mathrm{C}$ (Prabhu et al., 2015). The prepared sample suspension was then used for virus isolation.

\section{Virus isolation}

BPXV isolation on embryonated chicken eggs (ECEs)

Specific pathogen free (SPF) eggs were obtained from the production farm at Koum Osheim, El-Fayoum, Egypt. Eggs were kept in the incubator at $37^{\circ} \mathrm{C}$ with humidity of $40-60 \%$. They were used for virus isolation via inoculation of the prepared samples supernatants on the chorioallantoic membrane (CAM) of SPF embryonated chicken eggs at 9-11 days age (Prabhu et al., 2015). ECEs were examined for seven days for the detection of the appearance of pock lesions specific to buffalopox virus.

\section{BPXV isolation on tissue culture}

Baby hamster kidney (BHK) cell line

BHK cell line was obtained from the Central Laboratory for the Evaluation of Veterinary Biological Products (CLEVB) and propagated with Eagle's minimum essential medium (EMEM) and supplemented with $10 \%$ foetal bovine serum for virus isolation from the prepared samples supernatants (according to Goraya et al., 2015; Prabhu et al., 2015). A monolayer of BHK cell culture in a $75 \mathrm{~cm}^{2}$ flask inoculated with $0.5 \mathrm{~mL}$ supernatant was inoculated into confluent cell cultures and fed with maintenance medium containing bovine calf serum. The infected flasks were incubated at $37^{\circ} \mathrm{C}$ and were observed daily for cytopathic effect appearance (CPE) for seven days.

\section{VERO cell culture}

African green monkey kidney (Vero) cells were obtained from CLEVB for virus isolation and maintained (according to Yadav et al., 2010; Goyal et al., 2013). A monolayer of VERO cell culture in a $75 \mathrm{~cm}^{2}$ flask inoculated with $0.5 \mathrm{~mL}$ supernatant was inoculated into confluent cell cultures and fed with maintenance medium containing bovine calf serum. The infected flasks were incubated at $37^{\circ} \mathrm{C}$ and were observed daily for cytopathic effect appearance (CPE) for seven days.

\section{Nucleic acid extraction}

Viral DNA extractions from the samples (infected tissue culture samples) were performed using the QIAamp minielute virus spin kit (Qiagen, Germany, GmbH, Cat number 57704). Briefly, $200 \mu \mathrm{L}$ of the sample suspension was incubated with $25 \mu \mathrm{L}$ Qiagen protease and $200 \mu \mathrm{L}$ AL lysis buffer at $56^{\circ} \mathrm{C}$ for $15 \mathrm{~min}$. After incubation, $250 \mu \mathrm{L}$ $100 \%$ ethanol was added to the lysate. The samples were then washed and centrifuged following the manufacturer's recommendations. Nucleic acids were eluted with $100 \mu \mathrm{L}$ elution buffer.

\section{Oligonucleotide primers of the BPXV- specific $\mathrm{C} 18 \mathrm{~L}$ gene}

Forward: 5`-GCGGGTATCACTGTTATGAAACC-3'

Reverse: 5'-CATAAATACACTTTTATAGTCCTCG-3

According to Singh et al. (2008).

\section{PCR amplification}

The extracted nucleic acids samples were amplified by separate PCR reactions using the primer pair of the $\mathrm{C} 18 \mathrm{~L}$ gene in a $25 \mu \mathrm{L}$ reaction containing $12.5 \mu \mathrm{L}$ EmeraldAmp Max PCR Master Mix (Takara, Japan), $1 \mu \mathrm{L}$ of each primer of 20 pmoL concentration, $4.5 \mu \mathrm{L}$ water, and $6 \mu$ DNA template. The reactions were 
performed in an applied biosystem 2720 thermal cycler according to Yadav et al. (2010).

\section{Cycles of the PCR reaction}

The PCR reaction cycles were carried out as previously mentioned by Yadav et al. (2010). Primary denaturation: $94^{\circ} \mathrm{C}$ for 5 minutes. Amplification (35 cycles) as follows: Secondary denaturation: $94^{\circ} \mathrm{C}$ for 30 seconds, Annealing: $60^{\circ} \mathrm{C}$ for 40 seconds and Extension: $72^{\circ} \mathrm{C}$ for 50 seconds. Final extension: $72^{\circ} \mathrm{C}$ for 10 minutes.

\section{Analysis of the $P C R$ products}

The PCR products were separated by electrophoresis on $1.5 \%$ agarose gel (Applichem, Germany, GmbH) in $1 \mathrm{x}$ TBE buffer at room temperature using gradients of $5 \mathrm{~V} / \mathrm{cm}$. For gel analysis, 15 $\mu \mathrm{L}$ product was loaded into each gel slot. A generuler $100 \mathrm{bp}$ DNA ladder (Fermentas, Thermo, Germany) was used to determine fragment sizes. The gel was photographed by a gel documentation system (Alpha Innotech, Biometra).

\section{Animal ethics approval}

All procedures in this study met the ethics regulations of Cairo UniversityInstitutional Animal Care and Use Committee (CU-IACUC), which granted the study approval number: Vet CU28/04/2021/309.

\section{Results}

Generalized skin lesions of BPXV including erythema, papules, vesicle, pustules and scabs, distributed all over the skin of buffalos in different stages, as illustrated in Figures 1-3.

Drop in milk production, progressive emaciation, and poor quality skin were also recorded in BPXV infected buffaloes.

Typical pox lesions in human infected with BPXV (vesicle progressed into a pustule with a central area of necrosis) were observed on the hands and around the mouth of animal handlers with unilateral axillary lymphadenopathy and oedema on the arm of a buffalo owner as presented in Figure 4.

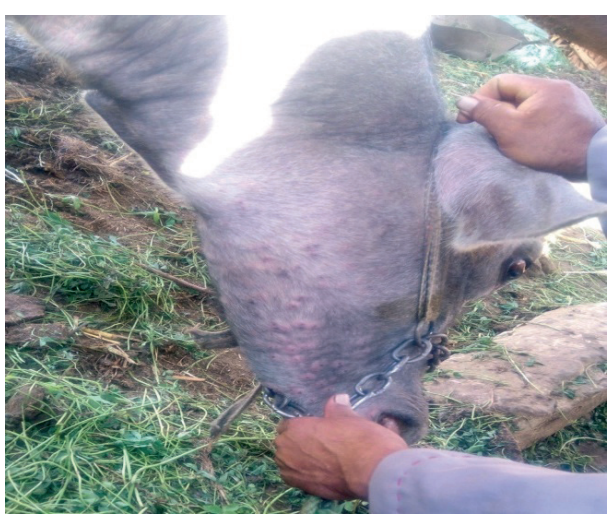

Figure 1. A recently buffalopox virus infected buffalo showed papules
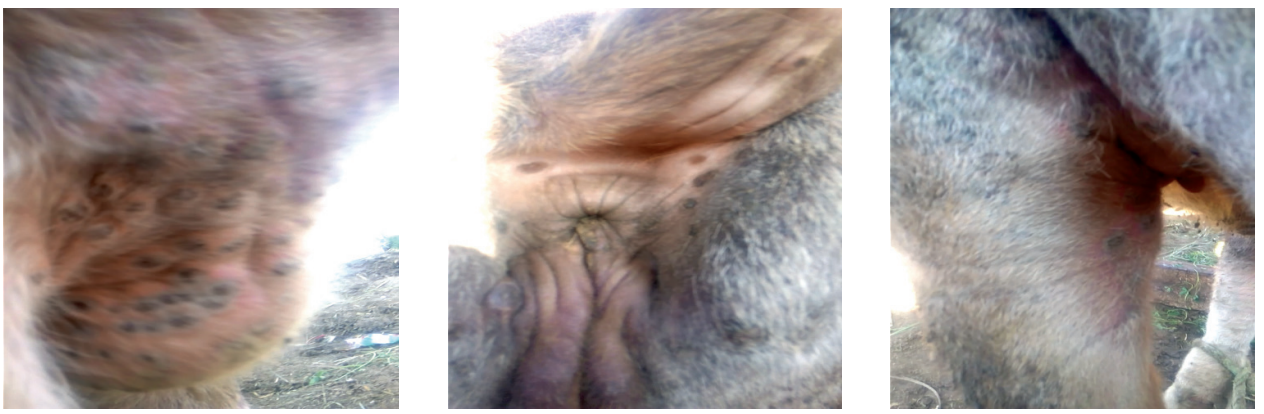

Figure 2. Buffalopox infected buffalo showed scabs on skin (at the sites brisket-perinium-groin) 


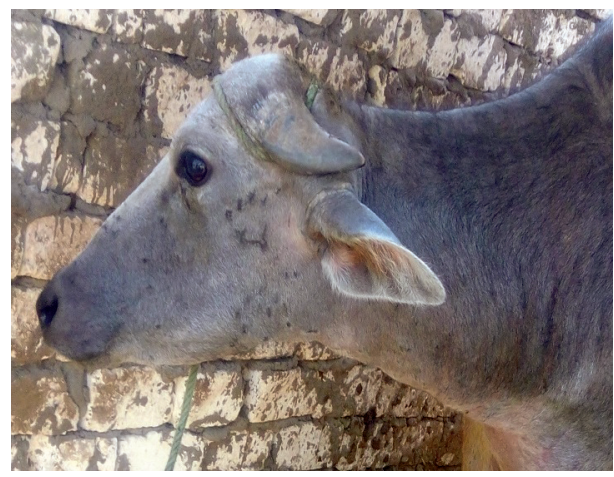

Figure 3. A recovered buffalo showed scar tissue formation at the sites of healing

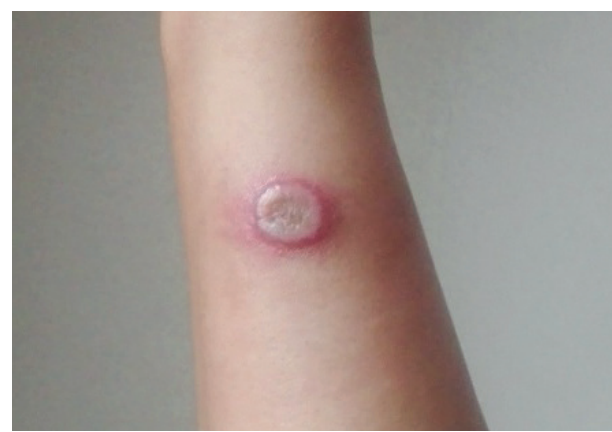

Figure 4. Buffalopox virus lesion on the arm of a buffalo owner

BPXV was isolated on ECE that showed clear raised white pocks lesions of pox on the CAM after three blind passages as shown in Figure 5.

Virus isolated on the tissue cultures (VERO cell line) after four blind passages as in Figure 6 and BHK cell line as in Figure 7 after three blind passages showing the cytopathic effect (CPE) included rounding, clumping with cytoplasmic granulation and cluster formation.

The molecular identification of BPXV using PCR for the C18L specific buffalo pox virus gene from two VERO isolated virus samples (T1 and T2) and three BHK isolated virus samples (T3, T4, T5) showed clear bands at $368 \mathrm{bp}$ as illustrated in Figure 8.

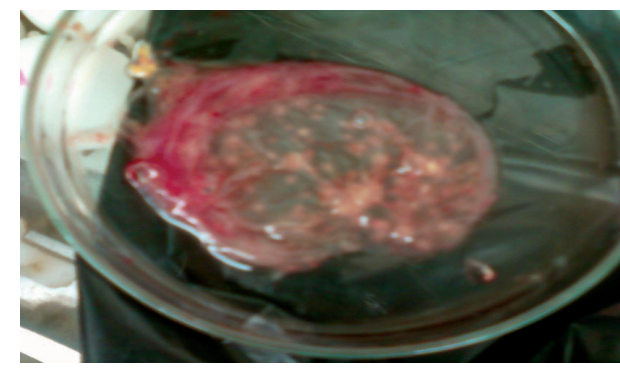

Figure 5. Pock lesion of the isolated buffalopox virus on the CAM of ECE

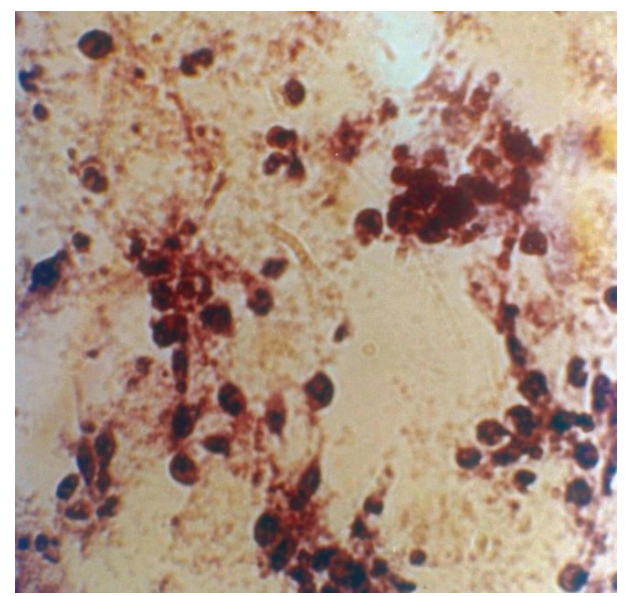

Figure 6. Cytopathic effect (CPE) of buffalopox virus on the VERO cell line

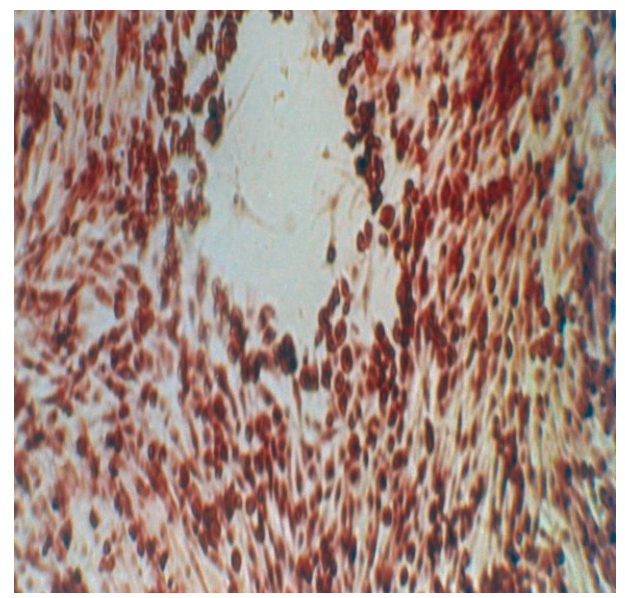

Figure 7. Cytopathic effect (CPE) of buffalopox virus on the BHK cell line. 


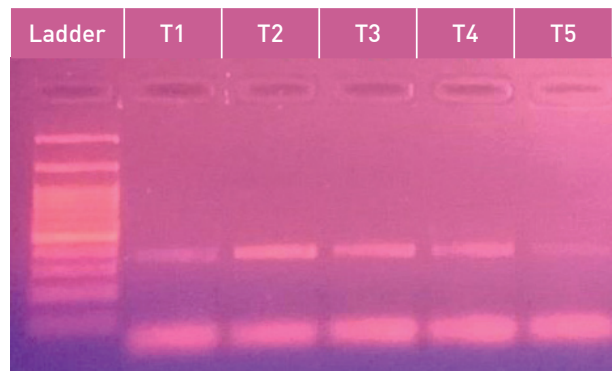

Figure 8. PCR reaction showed specific bands at $368 \mathrm{bp}$ for the five tested (T1, T2, T3, T4 and T5) extracted DNA samples from buffalopox infected tissue cultures for BPXV specific C18L gene

\section{Discussion}

Buffalo pox is a contagious viral disease of buffaloes that has an economic impact due to reduced milk yield resulting from mastitis and long periods of indigestion, drop in meat production and low hide quality. It also has zoonotic significance, and diagnostic tools are limited and there are no commercial vaccines available.

Clinical signs were recorded among the buffaloes in this study as mild and severe generalized forms, in different ages and both sexes. Generalized skin lesions of BPXV including erythema, papules, vesicle, pustules and scabs, distributed over the skins in different stages as shown in Figures 1 to 3. Drop in milk production, progressive emaciation, and poor quality skin were also recorded in the BPXV infected buffaloes.

These signs agree with literature reports (Singh, 2007; Bhanuprakash et al., 2010c; Yadav et al., 2010; Prabhu et al., 2015), confirming that occurrences of buffalo pox in buffaloes varies in morbidity, mortality and case fatalities rates, where mortality and case fatality rates are usually low.

The zoonotic infection of BPXV was observed in humans as presented in Figure 4 with lesions on the arm, hand and around the lips of infected buffalo owners. This observation agrees with previous reports (Singh et al., 2006a; Prabhu et al., 2015) and the assessment of the Joint Expert Committee on Zoonosis that the BPXV is an important potential zoonotic diseases, naturally transmitted in buffaloes and then consequently to humans. It also agrees with reports (Raut et al., 1997; Kolhapure et al., 1997; Singh et al., 2006a; 2007a) that stated that BPXV is a significant public health threat after the termination of vaccination against smallpox worldwide.

Isolation of BPXV was performed using embryonated chicken eggs (ECE), which showed typical pock lesions as shown in Figure 5. This is in agreement with previous reports (Prabhu et al., 2015; Eltom et al., 2020) that BPXV was isolated on ECE producing raised white pocks.

BPXV was isolated in cell lines (VERO and BHK cell lines) after blind passages as illustrated in Figures 6 and 7 which showed the cytopathic effects (CPE) also reported by Prabhu et al. (2015) and Eltom et al. (2020) that BPXV propagated in Vero and BHK21 cell lines show CPE including clumping and granulation, rounding, cluster formation and syncitia, and also agree with Yadav et al. (2010), Xu et al. (2014), and Afrough et al. (2018) who used VERO cell for buffalo pox virus isolation. Goraya et al. (2015) who used the BHK-21 cell in the isolation of the BPXV.

BPXV is close to the clade of VACV. In addition, studies on BPXV have revealed a close association between BPXV and the VACV envelope (Singh et al., 2006b and 2007b). Further, nucleotide and deduced amino acid sequences showed high identity with VACV (99\%), and the C18L gene showed that BPXV isolates clustered into a different group distinct from VACV (Singh et al., 2008 and 2012).

BPXV was identified and confirmed by PCR amplification of the BPXV specific C18L gene showing bands at $368 \mathrm{bp}$ (Figure 8) for the five tissue culture samples. This corresponds with 
the results of Singh et al. (2008) who developed a diagnostic PCR based on the C18L gene (368 bp) to differentiate BPXV from other members of OPV and to confirm the presence of BPXV infection. These results also agree with $\mathrm{Xu}$ et al. (2014), Eltom et al. (2020) and Borisevich et al., (2016) who recorded that the C18L gene encodes the ankyrin repeat protein, which determines the virus host range.

In Egypt, buffalo pox virus infection was first recorded in 1976 (Tantawi et al., 1976, 1977), when attempts were made for its isolation, cultivation and characterization. A new outbreak occurred in 2004 (Al Gaabary and Abuo Rawash, 2004), and its clinical, epidemiological and histopathological aspects were examined. Recently in 2019, BPXV infection reappeared with its zoonotic hazard; here we aimed to study BPXV using clinical, virological and molecular studies and characterization to expand the current knowledge about BPXV in Egypt as a means to achieve suitable rapid diagnostic techniques, implementations of therapeutic and preventives measures to restrict and control this disease and to avoid its zoonotic effects.

\section{Conclusion}

It was concluded that BPXV is circulating in Egypt and causing economic losses due to drops in milk and meat production, and the production of low quality of hide in infected buffaloes. BPXV infects buffaloes of different ages and sexes. It can be isolated on the CAM of ECE and also in different cell lines (VERO and BHK), and it was identified and confirmed by PCR for the BPXV specific $\mathrm{C} 18 \mathrm{~L}$ gene. BPXV has proven to have sporadic outbreaks, furthered by a zoonotic risk and economic impacts. Therefore, this infection should not be neglected and we should push for the development of a commercial vaccine to control its occurrence and hazards.

\section{References}

1. AFROUGH, B., A. ZAFAR, R. HASAN and R. HEWSON (2018): Complete genome sequence of buffalopox virus. Genome Announc. 6, 00444-18. 10.1128/genomeA.00444-18

2. AL GAABARY, M. H. and A. A. ABUO RAWASH (2004): Clinical, Epidemiological and Histopathological aspects of an outbreak of buffalopox. Assiut Vet. Med. J. 50, 157-171.

3. ANAND KUMAR, P. and G. BUTCHAIAH (2004): Partial Antigenic Characterization of Buffalopox Virus. Vet. Res. Commun. 28, 543-552. 10.1023/b:ver c.0000040245.85281.9a

4. BALAMURUGAN, V., V. BHANUPRAKASH, M. HOSAMANI, K. D. JAYAPPA, G. VENKATESAN, B. CHAUHAN and R. K. SINGH (2009): A polymerase chain reactin strategy for the diagnosis of camelpox. J. Vet. Diag. Invest. 21, 231-237. 10.1177/104063870902100209

5. BHANUPRAKASH, V., G. VENKATESAN, V. BALAMURUGAN, M. HOSAMANI, R. YOGISHARADHYA, P. GANDHALE, K. V. REDDY, A. S. DAMLE, H. N. KHER, B. S. CHANDEL, H. C. CHAUHAN and R. K. SINGH (2010): Zoonotic infections of buffalopox in India. Zoon. Public Health 57, e149-e155. 10.1111/j.18632378.2009.01314

6. BHATIA, S. N. (1936): Variola in ears and around eyes of buffaloes. Ind. Vet. J. 12, s236-237.

7. BORISEVICH, S. V., S. S. MARENNIKOVA, L. F. STOVBA, A. A. PETROV, V. T. KROTKOV and A. A. MAKHLAI (2016): Buffalopox Review article. Voprosy Virusologii 61, 200-204.

8. CABI (2019): Buffalopox- Animal disease. Datasheet. www. Cabi.org.

9. CHANDRA, R., I. P. SINGH, S. K. GARG, K. C. VARSHNEY (1986): Experimental pathogenesis of buffalopox in rabbits. Acta Virol. 30, 390-395.

10. ELTOM, K. H., A. M. SAMY, A. ABD EL WAHED and C. GERNY (2020): Buffalopox virus: An Emerging virus in livestock and humans. Pathogens 9:676. 10.3390/pathogens9090676

11. ESSBAUER, S., M. PFEFFER and H. MEYER (2010): Zoonotic Poxviruses. Vet. Microbiol. 140, 229-236. 10.1016/j.vetmic.2009.08.026

12. GHOSH, T. K., R. R. ARORA, C. L. SEHGAL, S. N. RAY and B. L. WATTAL (1977): An investigation of buffalopox outbreak in animals and human beings in Dhulia District (Mwaharastra State) Epidemiological studies. J. Com. Dis. 9, 146-147.

13. GORAYA, M. U., Z. A. QURESHI, M. ABBAS, M. ASHRAF and M. MUNIR (2015): Isolation of buffalo poxvirus from clinical case and variations in the genetics of the B5R gene over fifty passages. Virus Genes 51, 45-50. 10.1007/ s11262-015-1209-6 
14. GORE, S., A. GULANIKAR, C. RAJPUT, S. SHARMA, S. MALANI (2020): Uncommon cutaneous manifestations in buffalopox. IADVL 4, 146-148.

15. GOYAL, T., A. VARSHNEY, S. K. BAKSHI, S. BARUS, B. C. BERA, R. K. SINGH (2013): Buffalo pox outbreak with atypical features: A word of caution and need for early intervention! Int. J. Dematol. 52, 1224-1230. 10.1111/ijd.12120

16. GURAV, Y. K., C. G. RAUT, P. D. YADAV, B. V. TANDALE, A. A. SIVARAM, M. D. PORE, A. BASU, D. T. MOURY, and A. C. MISHRA (2011): "Buffalopox outbreak in Content is available under CC BY-SA 3.0 unless otherwise noted. humans and animals in Western Maharashtra, India". Prevent. Vet. Med. 100, 242-247. 10.1016/j. prevetmed.2011.03.008

17. KOLHAPURE, R. M., R. P. DEOLANKAR, C. D. TUPE, C. G. RAUT, A. BASU, B. M. DAMA, S. D. PAWAR, M. V. JOSHI, V. S. PADBIDRI, M. K. GOVERDHAN, K. BANERJEE (1997): Investigation of buffalopox outbreaks in Maharastra state during 1992-1996. Indian J. Med. Res. 106, 441-446.

18. MALLICK, K. P. (1988): A note on epidemiological study of an outbreak of buffalopox. Indian J. Vet. Med. 8, 146-147.

19. MALLICK, K. P. and S. K. DWIVEDI (1982): Clinical observations in an outbreak of buffalopox. Indian Vet. J. 59, 397-398.

20. MEYER, H. and H.J.RZIHA (1993): Characterization of the gene encoding the A-type inclusion protein of camel pox virus and sequence comparison with other orthopoxviruses. J. Gen. Virol. 4, 1679-1684. 10.1099/0022-1317-74-8-1679

21. MEYER, H., S. L. ROPP and J. J. ESPOSITO (1997): Gene for A-type inclusion body protein is useful for a polymerase chain reaction assay to differentiate orthopoxviruses. J. Virol. Meth. 64, 217-221. 10.1016/ S0166-0934(96)02155-6

22. PRABHU, M., R. YOGISHARADHYA, S. PAVULRAJ, C. SURESH, G. SATHISH and R. K. SINGH (2015): Camelpox and Buffalopox: Two Emerging and Re-emerging Orthopox Viral Diseases of India. Adv. Anim. Vet. Sci. 3, 527-541. 10.14737/journal.aavs/2015/3.10.527.541

23. RADOSTITS, O. M., C. C. GAY, K. W. HINCHCLIFF and P. D. CONSTABLE (2010): Veterinary medicine. In: A textbook of the diseases of cattle, horse, sheep, pig and goat, $10^{\text {th }}$ edition, Elsevier Saunders.

24. RAMAKRISHNA, M. and K. ANANTHAPADMANABHAM (1957): An experimental study of virus of buffalopox. Ind. Vet. J. 34, 23-30.

25. RAUT, C. G., S. B. TATWARTI, R. P. DEOLANKAR, R. M. KOLHAPURE, C. D. TUPE (1997): Buffalopox zoonosis in Nasik suburb (Maharastra State). Livest. Int. 1, 19. 10.1017/S1466252307001259

26. ROPP, S. L., Q. Y. JIN, J. C. KNIGHT, R. F. MASSUNG and J. J. ESPOSITO (1995): PCR strategy for identification and differentiation of smallpox and other orthopoxviruses. J. Clin. Microbiol. 33, 2069-2076. 10.1128/jcm.33.8.2069-2076.1995
27. SHARMA, G. K. (1934): An interesting outbreak of variola vaccinia in milk cattle of Lahore. The Imperial Council of Agricultural Research. Selected Clinical Articles. Miscellaneous Bull. 8, 1-4.

28. SINGH, I. P. and S. B. SINGH (1967): Isolation and characterization of the aetiologic agent of buffalopox. J. Res. Ludhiana. 4, 440 .

29. SINGH, R. K., M. HOSAMANI, V. BALAMURUGAN, C. C. SATEESH, K. R. SINGHAL, V. RAMTEKE and M. P. YADAV (2006a): An outbreak of buffalopox in buffalo (Bubalus bubalis) dairy herds at Aurangabad, India. Rev. Sci. Tech. 25, 981-987.

30. SINGH, R. K., M. HOSAMANI, V. BALAMURUGAN, C. C. SATEESH, T. J. RASOOL and M. P. YADAV (2006b): Comparative sequence analysis of envelope protein genes of Indian buffalo pox virus isolates. Arch Virol. 151, 1995-2005. 10.1007/s00705-006-0761-8

31. SINGH, R. K., M. HOSAMANI, V. BALAMURUGAN, V. BHANUPRAKASH, T. J. RASOOL and M. P. YADAV (2007): "Buffalopox: An emerging and reemerging zoonosis". Anim. Health Res. Rev. 8, 105-114. 10.1017/S1466252307001259

32. SINGH, R. K., V. BALAMURUGAN, M. HOSAMANI, D. J. KALLESH and V. BHANUPRAKASH (2008): Sequence analysis of C18L gene of buffalopox virus: PCR strategy for specific detection and differentiation of buffalopox from orthopoxviruses. J. Virol. Methods. 154, 146153. 10.1016/j.jviromet.2008.08.009

33. SINGH, R. K., V. BALAMURUGAN, V. BHANUPRAKASH, G. VENKATESAN and $\mathrm{M}$. HOSAMANI (2012): Emergence and reemergence of vaccinia-like viruses: global scenario and perspectives. Indian J. Virol. 23, 1-11. 10.1007/ s13337-012-0068-1

34. TANTAWI, H. H., A. A. FAYED and M. A. SHALABY (1977): Isolation, cultivation and characterization of poxviruses from Egyptian water buffaloes. J. Egypt Vet. Med. Assoc. 37, 15-23.

35. TANTAWI, H. H., Y. KHAMIS, M. S. SABER, M. A. SHALABY and M. S. OMAR (1976): Isolation and characterization of poxvirus from buffalo teat's lesions in Egypt. J. Egypt Vet. Med. Assoc. 36, 151-159.

36. VAN REGENMORTEL, M. H. V., C. M. FAUQUET and D. H. L. BISHOP (2000): Virus taxonomy: Seventh Report of the International committee on taxonomy of Viruses. Academic Press, San Diego.

37. VENKATESAN, G., V. BALAMURUGAN, M. PRABHU, R. YOGISHARADHYA, D. P. BORA, P. N. GANDHALE, M. S. SANKAR, R. K. KULKARNI and S. V. BHANUPRAKASH (2010a): Emerging and re-emerging zoonotic buffalopox infection: a severe outbreak in Kolhapur (Maharashtra), India. Vet. Ital. 46, 439-448.

38. VENKATESAN, G., V. BALAMURUGA, P. N. GANDHALE, R. K. SINGH and V. BHANUPRAKA (2010b): Viral Zoonosis: A Comprehensive 
Review". Asian J. Ani. Vet. Adv, 5, 77-92. 10.3923/ ajava.2010.77.92

39. WARIYAR, K. C. (1937): Variola in buffaloes. Ind. Vet. J. 14, 169-170.

40. XU, Q., J. CASEY and M. PICHICHERO (2014): Laboratory acquired Buffalopox Virus Infection, India. Emerg. Infect. Dis. 20, 325-327. 10.3201/ eid2002.130358
41. YADAV, S., M. HOSAMANI, V. BALAMURUGAN, V. BHANUPRAKASH and R. K. SINGH (2010): Partial genetic characterization of viruses isolated from pox-like infection in cattle and buffaloes: evidence of buffalo pox virus circulation in Indian cows. Arch. Virol. 155, 255-261. 10.1007/s00705-0090562-y

\section{Virološko i molekularno istraživanje na uzorcima bizona pod sumnjom da su zaraženi virusom bizonskih boginja u Egiptu 2019. godine}

Christine A. MIKHAEL, Farid F. ZAKI, Agriculture Research Center (ARC); Central Laboratory for Evaluation of Veterinary Biologics (CLEVB), El-Seka-Baida Street, Abbasia, Cairo, Egypt; Fayez A. SALIB, Faculty of Veterinary Medicine, Cairo University, Egypt

U ovoj studiji lezije kože bizona koje su pokazivale kliničke znakove infekcije bizonskim boginjama, rabljene su za izoliranje i identifikaciju virusa bizonskih boginja (BPXV). Provedeno je kliničko ispitivanje zaraženih bizona i zabilježeni su očiti klinički znaci. Kraste s kože zaraženih bizona su prikupljene i rabljene za izolaciju virusa na embrioniranom kokošjem jajetu (ECE) te linijama tkivnih staničnih kultura. Izolirani BPXV identificiran je i okarakteriziran uporabom lančane reakcije polimerazom (PCR). Zaraženi bizoni imali su vrućicu, osip na koži, povećanje površinskih limfnih čvorova, mršavjeli su, a i došlo je do pada proizvodnje mlijeka. ECE cijepljeni pripremljenim uzorcima krasta skože pokazali su jasne uzdignute bijele lezije boginja na korioalantoičnoj membrani (CAM). Cijepljene tkivne kulture (VERO i BHK stanične linije) otkrile su citopatski učinak (CPE), uključujući zaobljivanje, agregaciju $\mathrm{s}$ granulacijom citoplazme i formiranje klastera. PCR za C18L specifični gen virusa bizonskih boginja proveden je na tkivnoj kulturi zaraženoj virusom proizvevši 368 bp vrpci. Zabilježena je i zaraza ljudi BPXV-om. Zaključeno je da BPXV kruži među egipatskim bizonima, što prouzroči, dođu li u kontakt s BPXV zarazu ljudi i velike ekonomske gubitke.

Ključne riječi: bizonske boginje, virološki, molekularno, dijagnoza, Egipat 